\title{
JENIS DAN KANDUNGAN ANTOSIANIN BUAH TOMI-TOMI
}

\author{
[The Anthocyanin's Types and Content of Batoko Plum Fruit]
}

\author{
Rema Fitriyani, Lydia Ninan Lestario*, dan Yohanes Martono \\ Program Studi Kima, Fakultas Sains dan Matematika, Universitas Kristen Satya Wacana, Salatiga
}

Diterima 18 April 2018 / Disetujui 20 September 2018

\begin{abstract}
Batoko plum fruit (Flacourtia inermis, Roxb) is one of the plants that contains anthocyanins. The fruit has purplish red color and was thought to benefit health by reducing blood sugar levels, as anti-hypertension agents or antioxidants. The aim of this research was to determine the total anthocyanin content and identify the type of anthocyanidin and anthocyanin of batoko plum fruit. The total anthocyanin content of batoko plum fruit which determined by differential $\mathrm{pH}$ method was $26.56 \pm 0.28 \mathrm{mg} / 100 \mathrm{~g}$ (w.b.) or $103.89 \pm 1.08 \mathrm{mg} / 100 \mathrm{~g}$ (d.b.). Based on the Rf value on TLC and the peak retention time in HPLC, it was confirmed that the anthocyanin was delfinidine. However, the wavelength maximum absorbance data of the TLC spot showed the presence of cyanidine. These results were possibly caused by the use of too diluted extracts or the degradation of the anthocyanin during acid hydrolysis. Based on the Rf value on TLC and glucosidation pattern in UV-Vis spectrophotometer, it is suspected that cyanidine 3-glucoside and delfinidine 3-glucoside were present.
\end{abstract}

Keywords: anthocyanidin, anthocyanins, batoko plum fruit

\begin{abstract}
ABSTRAK
Tomi-tomi (Flacourtia inermis, Roxb) adalah salah satu tanaman yang mengandung antosianin. Buahnya memiliki warna merah keunguan dan memiliki banyak manfaat untuk kesehatan seperti menurunkan kadar gula darah, anti hipertensi, dan antioksidan. Tujuan dari penelitian ini adalah untuk menentukan kandungan antosianin total dan mengidentifikasi jenis antosianidin dan antosianin buah tomi-tomi. Kandungan antosianin total buah tomi-tomi yang ditentukan dengan metode perbedaan $\mathrm{pH}$ adalah $26,56 \pm 0,28 \mathrm{mg} / 100 \mathrm{~g}$ berat segar atau 103,89 $\pm 1,08 \mathrm{mg} / 100 \mathrm{~g}$ berat kering. Berdasarkan nilai Rf pada kromatografi lapis tipis (KLT) dan waktu retensi puncak HPLC, dipastikan bahwa antosianidin jenis delfinidin. Namun, data absorbansi panjang gelombang maksimum pada spot KLT menunjukkan sianidin. Mungkin, ini dikarenakan ekstrak yang digunakan terlalu encer atau antosianidin telah terdegradasi selama proses hidrolisis. Berdasarkan nilai Rf pada KLT dan pola glikosidasi pada Spektrofotometer UV-Vis, diduga antosianin jenis Sianidin 3-glukosida dan delfinidin 3-glukosida.
\end{abstract}

Kata kunci: antosianidin, antosianin, tomi-tomi

\section{PENDAHULUAN}

Antosianin merupakan pigmen yang tersebar luas dalam tumbuhan. Pigmen yang berwarna merah jambu, merah, ungu, dan biru dapat larut dalam air dan banyak terdapat dalam buah dan sayuran (Stefanut et al., 2011). Antosianin merupakan suatu senyawa turunan flavonoid yang memiliki kemampuan sebagai antioksidan. Antosianin terdiri dari gugus gula (glikon), gugus bukan gula yaitu antosianidin (aglikon), dan ada beberapa antosianin mengandung gugus asil. Selain itu juga antosianin dalam bentuk aglikon lebih aktif dibandingkan bentuk glikosidanya (Ali et al.,2013).

*Penulis Korespondensi:

E-mail: nlestario@gmail.com; remafitriyani10@gmail.com
Antosianin memiliki beberapa aktivitas farmakologi, salah satunya anti inflamasi yang terkait dengan struktur kimianya dan dapat menangkap radikal bebas sehingga berperan untuk mencegah terjadi penuaan, kanker, dan penyakit degeneratif (Reis et al., 2016). Selain itu, antosianin juga memiliki kemampuan sebagai anti karsinogenik, mencegah gangguan fungsi hati, anti hipertensi, dan menurunkan kadar gula darah (Husna et al., 2013). Sampai sekarang telah diidentifikasi lebih dari 540 pigmen antosianin yang ada di alam. Namun yang paling banyak dijumpai yaitu: sianidin, delfinidin, peonidin, petunidin, dan malvidin (Weber dan Larsen, 2017).

Tomi-tomi (Flacourtia inermis, Roxb) merupakan salah satu tanaman yang tumbuh di Indonesia. Tomi-tomi mengandung antosianin karena buahnya berwarna merah keunguan. Tomi-tomi banyak di- 
jumpai di hutan Maluku dan daerah Indonesia lainnya. Tomi-tomi memiliki aneka nama di daerah penyebarannya, seperti rukam masam, lovi-lovi (Malaysia), patoko plum (Filipina), takhop-thai (Thailand), lokia, lavalolika (Kerala, India), tomi-tomi (Maluku), lubi-lubi (Minangkabau). Buah ini memiliki rasa sangat asam, hanya sedikit rasa manis sehingga sering dimanfaatkan untuk rujak, selai, asinan, manisan, atau juga sirup (Sotyati, 2016).

Sejauh ini, penelitian tentang buah tomi-tomii masih sulit ditemui. Namun, dalam penelitian yang dilakukan Latumaerissa et al. (2017) kandungan antosianin dalam buah tomi-tomi matang yang diambil dari Saparua, Provinsi Maluku, Ambon adalah $141,27 \pm 0,199 \mathrm{mg} / 100 \mathrm{~g}$ berat basah. Kandungan antosianin buah tomi-tomi memberikan aktivitas antioksidan pada pengujian penangkapan radikal DPPH dengan nilai $\mathrm{IC}_{50}$ sebesar $67,6 \mu \mathrm{g} / \mathrm{L}$ dan $0,0179 \pm$ $0,001 \mathrm{~g} / \mathrm{mEk} \mathrm{K}_{4} \mathrm{Fe}(\mathrm{CN})_{6}$ berdasarkan uji kemampuan mereduksi. Asupan sari buah tomi-tomi pada dosis $55,90 \mathrm{mg} / \mathrm{kg}$ BB selama 3 minggu menghasilkan persentase penurunan konsentrasi kolesterol total pada mencit (70,78\%) (Latumaerissa et al., 2017). Penelitian tentang identifikasi jenis antosianin buah tomi-tomi belum pernah dilakukan sebelumnya, sehingga pada penelitian ini bertujuan untuk menentukan kandungan antosianin total buah tomi-tomi yang tumbuh di tanah Salatiga dan mengidentifikasi jenis antosianidin dan antosianin buah tomi-tomi (Flacourtia inermis, Roxb).

\section{BAHAN DAN METODE}

\section{Bahan}

Bahan utama yang digunakan adalah buah tomi-tomi yang dipetik dari pohon yang tumbuh di Universitas Kristen Satya Wacana Salatiga, Jawa Tengah.

\section{Preparasi sampel}

Buah tomi-tomi yang sudah matang dicuci bersih lalu ditiriskan. Sampel dikeringkan dengan pengeringan beku (Power-day LL 1500, Thermoscientific, Republik Ceko). Kemudian sampel yang sudah kering dihaluskan dengan grinder (Philips, Belanda) hingga menjadi serbuk. Sampel disimpan dalam wadah tertutup dan dimasukkan ke dalam freezer suhu $2^{\circ} \mathrm{C}$ (LG GN-B202 RLCL).

\section{Ekstraksi dan penentuan kadar antosianin total buah tomi-tomi (Sutharut dan Sudarat, 2012)}

Sebanyak 2,0106 g serbuk buah tomi-tomi kering (kadar air 21,70\%) dimaserasi dengan $20 \mathrm{~mL}$ metanol-HCl $1 \%$ (Merck, Jerman) pada suhu $\pm 5^{\circ} \mathrm{C}$ selama semalam. Filtrat ditampung dalam labu ukur $50 \mathrm{~mL}$ dan residu dimaserasi kembali dengan pelarut yang sama (10 dan $5 \mathrm{~mL}$ ) sebanyak dua kali, masing-masing selama 30 menit. Ekstraksi dilakukan sampai warna merah pada filtrat tidak berwarna lagi (bening). Penentuan kadar antosianin total ekstrak buah tomi-tomi diukur dengan metode perbedaan $\mathrm{pH}$. Ekstrak antosianin dimasukkan ke dalam dua tabung reaksi. Tabung pertama ditambahkan dengan bufer $\mathrm{KCl}-\mathrm{HCl}(\mathrm{pH} \mathrm{1)}$ (Merck, Jerman) yang diinkubasi selama 15 menit dan tabung kedua ditambahkan bufer NaOAc ( $\mathrm{pH} 4,5)$ (Merck, Jerman) yang diinkubasi selama 5 menit dengan perbandingan ekstrak terhadap bufer 0,9:3,1 (v/v). Masingmasing tabung diukur absorbansinya menggunakan spektrofotometer UV-Vis (Optizen UV 2120) pada panjang gelombang 510 dan 700 nm. Ekstraksi dan penentuan kadar antosianin dilakukan sebanyak tiga kali ulangan dengan pengamatan triplo.Konsentrasi antosianin sampel dihitung mengikuti Hukum Lambert-Beer:

$A=\varepsilon b c$

Absorbansi sampel dihitung dengan rumus:

$$
A=\left[\left(A_{510}-A_{700}\right)_{p H 1}-\left(A_{510}-A_{700}\right)_{p H 4,5}\right]
$$

dimana, $\varepsilon$ adalah koefisien ekstingsi molar sianidin3-glukosida, yaitu 29.600 L.mol ${ }^{-1} . \mathrm{cm}^{-1}$ dengan berat molekul sebesar $448,8 \mathrm{~g} / \mathrm{mol}$. b adalah lebar kuvet, yaitu $1 \mathrm{~cm}$ dan $\mathrm{c}$ adalah konsentrasi antosianin $\left(\mathrm{mol} . \mathrm{L}^{-1}\right)$.

\section{Ekstraksi antosianidin (Harborne, 1987)}

Sebanyak 2,03 g sampel dipanaskan dalam 8 mL HCl 2 M (Merck, Jerman) selama 40 menit pada suhu $100^{\circ} \mathrm{C}$. Ekstrak didinginkan menggunakan serpihan es, kemudian disaring dan filtrat dicuci dengan $5 \mathrm{~mL}$ etil asetat (Merck, Jerman) sebanyak 2 kali. Fraksi etil asetat dibuang dan lapisan air diuapkan diatas rotary evaporator (BUCHI R-114) pada suhu $80^{\circ} \mathrm{C}$ untuk menguapkan sisa etil asetat. Ekstrak yang telah dicuci dengan etil asetat, kemudian dilarutkan dengan $4 \mathrm{~mL}$ amil alkohol (Merck, Jerman) untuk memisahkan ekstrak antosianidin dan gula, fraksi amil alkohol (fraksi atas) diambil dan diuapkan dalam gelas arloji di atas rotary evaporator (BUCHI $\mathrm{R}-114)$ bersuhu $90^{\circ} \mathrm{C}$, fraksi bawah atau fraksi air berwarna kuning merupakan gula. Ekstrak antosianidin (fraksi atas) yang telah kering dilarutkan dalam $\pm 1 \mathrm{~mL}$ metanol-HCl 0,1\% (Merck, Jerman).

\section{Penentuan jenis antosianidin dengan kromato- grafi lapis tipis (KLT) (Harborne, 1996)}

KLT dilakukan dengan cara menotolkan pipa kapiler pada ekstrak antosianidin, kemudian pipa kapiler ditotolkan pada plat selulosa (Merck, Jerman). Plat selulosa kemudian dikeringkan dengan diuapi gas $\mathrm{N}_{2}$, pemisahan dengan KLT menggunakan fase gerak Format $(\mathrm{HCl}$ pekat:asam format: akuades = 
2:5:3, v/v/v), Forestal ( $\mathrm{HCl}$ pekat:asam asetat:akuades $=3: 30: 10, v / v / v)$ dan BAA (n-butanol:asam asetat:akuades $=4: 1: 5, \mathrm{v} / \mathrm{v} / \mathrm{v}$ ) (Merck, Jerman). Spot dari hasil KLT dicatat warna visual, visualisasi, dan nilai Rf dari masing-masing spot sebagai dasar untuk menentukan jenis antosianidin yang dicocokkan dengan tabel referensi (Tabel 1).

Pemindaian panjang gelombang maksimum dengan spektrofotometer UV-Vis (Harborne, 1987)

Ekstrak antosianidin dipisahkan dengan KLT preparatif, dengan jumlah sampel yang lebih banyak (3,05 g) dan fase gerak yang menghasilkan pemisahan terbaik. Setelah spot terpisah dengan baik, spot hasil pemisahan dikerok dan dilarutkan dengan metanol-HCl 0,1\% (Merck, Jerman) diaduk sampai warnanya muncul. Sampel disaring dengan kertas whatman no. 1 dan dipindai panjang gelombang maksimumnya pada daerah 200-800 nm. Blanko

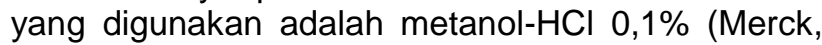
Jerman). Kemudian ditambahkan dengan beberapa tetes $\mathrm{AlCl}_{3}(5 \% \mathrm{~b} / \mathrm{v}$ dalam metanol), diamati perubahan warnanya dan dipindai kembali panjang gelombang maksimumnya untuk melihat ada tidaknya pergeseran batokromik.

Analisis antosianidin dengan kromatografi cair kinerja tinggi (KCKT) (Alvionita et al., 2016)

Penentuan jenis antosianidin dengan KCKT (Knauer Smartline 5000, Smartline pump 1000) yang dimodifikasi. Ekstrak antosianidin diinjeksikan ke dalam sistem KCKT dengan kondisi operasional sebagai berikut: Fase diam = Eurosphere RPC-18, $(150 \times 4,6 \mathrm{~mm}, 5 \mu \mathrm{m})$. Fase gerak $=10 \%$ asam format (dalam air):asetonitril $(85: 15 \mathrm{v} / \mathrm{v})$. Kecepatan alir= $1,2 \mathrm{~mL} / \mathrm{menit}$. Volume injeksi $=20 \mathrm{~mL}$. Detektor: UV, pada $\lambda 530 \mathrm{~nm}$.

\section{Identifikasi jenis gula (Harborne, 1987)}

Fraksi air dari hasil hidrolisis asam diuapkan dengan rotary evaporator (BUCHI R-114) pada suhu $45^{\circ} \mathrm{C}$. Gula diidentifikasi dengan kromatografi lapis tipis (KLT-silika gel $60 \mathrm{~F}_{254}$ ) dengan fase gerak BAA (n-butanol:asam asetat:akuades $=4: 1: 5$ ) dan BEA (n-butanol:etanol:akuades $=4: 1: 2,2 \mathrm{v} / \mathrm{v} / \mathrm{v})$ (Merck,
Jerman). Pada identifikasi jenis gula ini juga digunakan standar glukosa. Standar glukosa dibuat dari 0,1 glukosa (Merck, Jerman), dilarutkan dalam $1 \mathrm{~mL}$ akuades. Spot hasil KLT gula divisualisasi menggunakan pereaksi anilina hidrogen ftalat. Kertas KLT dipanaskan pada suhu $105^{\circ} \mathrm{C}$ selama 5 menit agar warna khasnya timbul. Kertas harus diperiksa dengan sinar UV agar warna dapat terlihat dengan lebih jelas.

\section{Penentuan jenis antosianin dengan kromatografi lapis tipis (KLT) (Harborne, 1996)}

Ekstrak antosianin dipekatkan di atas gelas arloji pada suhu $45^{\circ} \mathrm{C}$ dan dilarutkan dalam $\pm 1 \mathrm{~mL}$ metanol-HCl 0,1\% (Merck, Jerman). Kemudian ditotolkan pada plat selulosa (Merck, Jerman) dan dikeringkan dengan diuapi gas $\mathrm{N}_{2}$, pemisahan ini menggunakan fase gerak BAA (n-butanol:asam asetat: akuades $=4: 1: 5, \mathrm{v} / \mathrm{v} / \mathrm{v})$, BuHCl (n-butanol: $\mathrm{HCl} 2 \mathrm{M}=$ $1: 1, \mathrm{v} / \mathrm{v}$ ) dan $\mathrm{HCl} 1 \%$ (akuades: $\mathrm{HCl}$ pekat = 97:3, v/v) (Merck, Jerman). Spot dari hasil KLT dicatat warna visual, visualisasi dan nilai Rf dari masingmasing spot sebagai dasar untuk menentukan jenis antosianin.

\section{Penentuan absorbansi maksimum dengan spek- trofotometer UV-Vis (Markakis, 1982)}

Pada penentuan KLT diperoleh pemisahan yang baik, sehingga dilakukan KLT preparatif menggunakan fase gerak yang menghasilkan pemisahan terbaik, dengan jumlah sampel yang lebih banyak. Setelah spot terpisah dengan baik, spot hasil pemisahan dikerok dan dilarutkan dengan metanol-HCl $0,1 \%$ (Merck, Jerman) diaduk sampai warnanya muncul. Sampel disaring dengan kertas whatman dan ekstrak antosianin dipindai absorbansi maksimumnya pada daerah 200-800 nm. Ekstrak antosianin juga dipindai absorbansinya pada $440 \mathrm{~nm}$ untuk menentukan rasio yang mencerminkan posisi ikatan glikosidanya.

Rasio $=\frac{\mathrm{A} 440 \mathrm{~nm}}{\mathrm{~A} 1 \mathrm{maks}}$

Tabel 1. Tabel referensi untuk ciri antosianidin umum

\begin{tabular}{|c|c|c|c|c|c|c|}
\hline \multirow{2}{*}{ Pigmen } & \multicolumn{3}{|c|}{ Rf $(\times 100)$ dalam } & \multirow{2}{*}{ Warna Tampak } & \multirow{2}{*}{$\begin{array}{l}\text { A Maksimum }(\mathrm{nm}) \\
\text { dalam } \mathrm{MeOH}-\mathrm{HCl}\end{array}$} & \multirow{2}{*}{$\begin{array}{l}\text { Geser Warna } \\
\text { dengan } \mathrm{AlCl}_{3}\end{array}$} \\
\hline & Forestal & Format & BAA & & & \\
\hline Pelargonidin & 68 & 30 & 80 & Merah & 520 & - \\
\hline Sianidin & 49 & 22 & 68 & Merah lembayung & 535 & + \\
\hline Peonidin & 63 & 30 & 71 & Merah lembayung & 532 & - \\
\hline Delfinidin & 32 & 13 & 42 & Lembayung & 546 & + \\
\hline Petunidin & 46 & 20 & 52 & Lembayung & 543 & + \\
\hline Malvidin & 60 & 27 & 58 & Lembayung & 542 & - \\
\hline
\end{tabular}

Keterangan: Forestal $=\mathrm{HCl}$ pekat:asam asetat:akuades $(3: 30: 1, \mathrm{v} / \mathrm{v} / \mathrm{v}) ;$ Format $=\mathrm{HCl}$ pekat:asam format:akuades $(2: 5: 3$, v/v/v); BAA = n-butanol:asam asetat:akuades $(4: 1: 5, v / v / v)($ Harborne, 1987) 


\section{Analisis data}

Pengukuran kandungan antosianin total dilakukan dengan 3 kali ulangan masing-masing triplo dan penentuan jenis antosianin dan antosianidin tidak dilakukan analisa data secara statistik, tetapi setiap tahap dilakukan berulang-ulang sampai diperoleh pemisahan yang baik sesuai dengan standar (nilai Rf dan $\lambda$ maks).

\section{HASIL DAN PEMBAHASAN}

\section{Antosianin total}

Hasil pengukuran kandungan antosianin total dengan metode perbedaan $\mathrm{pH}$ buah tomi-tomi sebesar $26,56 \pm 0,28 \mathrm{mg} / 100 \mathrm{~g}$ (berat basah) atau 103,89 $\pm 1,08 \mathrm{mg} / 100 \mathrm{~g}$ (berat kering). Kandungan antosianin yang dihasilkan pada penelitian ini lebih rendah jika di bandingkan dengan penelitian Latumaerissa et al. (2017), yaitu $26,56 \pm 0,28 \mathrm{mg} / 100 \mathrm{~g}$ (berat basah). Hal ini mungkin dikarenakan lokasi penanaman buah ini berbeda yaitu pada penelitian Latumerissa et al. (2017) menggunakan buah tomitomi yang tumbuh di Maluku, sedangkan pada penelitian ini menggunakan buah tomi-tomi yang tumbuh di Salatiga. Hal ini mungkin kesuburan tanah yang berbeda, iklim atau jenis buah yang belum tentu sama, ketinggian tempat, suhu udara dan cahaya. Selain itu juga, mungkin disebabkan oleh buah yang digunakan tingkat kematangan, warna dan umur yang berbeda, sehingga akan memengaruhi hasil kandungan antosianin buah tersebut (Anggriani et al., 2017). Pada penelitian Latumerissa et al. (2017) sari buah tomi-tomi digunakan secara in vivo pada tikus atau mencit untuk menentukan penurunan kadar kolestrol darah tikus percobaan, sedangkan pada penelitian ini ditujukkan untuk menentukan jenis antosianidin dan antosianin yang ada pada buah tomitomi.

\section{Jenis antosianidin}

Antosianidin merupakan aglikon dari antosianin, sehingga langkah awal untuk identifikasi yaitu menentukan jenis antosianidinya. Antosinidin yang umum dijumpai hanya terdapat 6 jenis antosianidin utama, yaitu pelargonidin, sianidin, delfinidin, peonidin, petunidin, dan malvidin (Weber dan Larsen, 2017). Jenis antosianidin dapat ditentukan dengan menggunakan kromatografi lapis tipis (KLT). Antosianidin dilakukan berdasarkan warna, nilai $\mathrm{Rf}$, dan panjang gelombang maksimum pada hasil KLT dan analisis KCKT. Prinsip kromatografi adalah perbedan adsorpsi atau partisi fase diam (adsorben) dengan fase gerak (Lestari et al., 2014). Pada penelitian ini fase diam yang digunakan pada KLT adalah plat selulosa, dikarenakan warna bercak yang dihasilkan tidak mudah pudar setelah pemisahan (Harborne, 1987) dan fase gerak yang digunakan adalah forestal, format, dan BAA (n-butanol:asam asetat:akuades). Hasil pemisahan antosianidin (hidrolisis asam) dengan KLT dapat dilihat pada Gambar 1 dan Tabel 2.

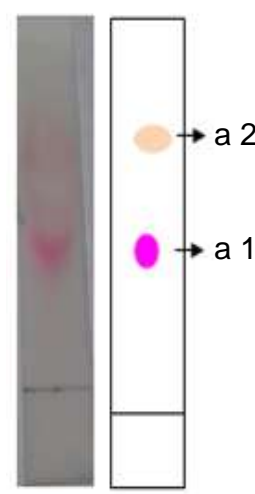

Forestal

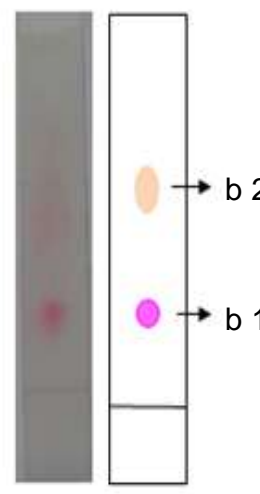

Format

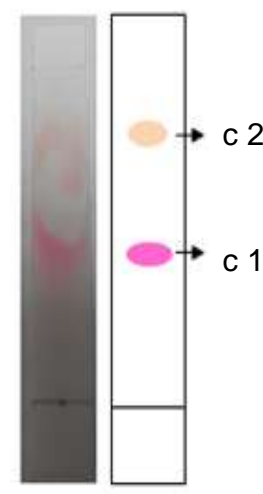

BAA
Keterangan: Jarak atas pergerakan pelarut forestal, format dan BAA berturut-turut adalah 6,$3 ; 5,7$; dan $5,2 \mathrm{~cm}$. Jarak batas bawah dan atas pelarut forestal, format dan BAA berturut-turut adalah 7,0; 6.5; dan $6,0 \mathrm{~cm}$. Jarak pergerakan spot pelarut forestal, format dan BAA berturut-turut adalah 2,2; 0,8; dan $2,2 \mathrm{~cm}$

Gambar 1. Kromatogram antosianidin buah tomitomi dengan KLT. Fase diam:plat selulosa. Fase gerak:Forestal $(\mathrm{HCl}$ pekat: asam asetat:akuades $=3: 30: 10, \mathrm{v} / \mathrm{v} / \mathrm{v})$, Format $(\mathrm{HCl}$ pekat:asam format: akuades $=2: 5: 3, \mathrm{v} / \mathrm{v} / \mathrm{v}$ ), dan BAA (butanol: asam asetat:akuades $=4: 1: 5, \mathrm{v} / \mathrm{v} / \mathrm{v}$ )

Pada Gambar 1 terlihat bahwa buah tomi-tomi menghasilkan 2 spot, spot 1 berwarna ungu dan spot 2 berwarna coklat muda. Spot berwarna coklat muda ini bukan termasuk antosianidin, karena tidak ada antosianidin yang berwarna coklat dan kemungkinan senyawa tersebut adalah flavon, yang termasuk golongan flavonoid (Harborne, 1987).

Tabel 2. Nilai Rf KLT antosianidin buah tomi-tomi dengan fase gerak forestal, format, dan BAA ( $n$-butanol: asam asetat:akuades)

\begin{tabular}{|c|c|c|c|c|}
\hline Fase gerak & $\mathrm{Rf} \times 100$ & Warna Tampak & Warna UV $254 \mathrm{~nm}$ & Pendugaan* ${ }^{\star}$ \\
\hline Forestal & $\begin{array}{l}(\text { a.1) }=34,92 \\
\text { (a.2) }=69,84\end{array}$ & $\begin{array}{c}\text { Ungu } \\
\text { Coklat muda }\end{array}$ & $\begin{array}{c}\text { Ungu } \\
\text { Coklat }\end{array}$ & Delfinidin \\
\hline Format & $\begin{array}{l}(\text { b.1) }=14,03 \\
\text { (b.2) }=56,25\end{array}$ & $\begin{array}{l}\text { Ungu } \\
\text { Coklat muda }\end{array}$ & $\begin{array}{l}\text { Ungu } \\
\text { Coklat }\end{array}$ & Delfinidin \\
\hline BAA & $\begin{array}{l}(c .1)=42,31 \\
\text { (c.2) }=75,00\end{array}$ & $\begin{array}{l}\text { Ungu } \\
\text { Coklat muda }\end{array}$ & $\begin{array}{l}\text { Ungu } \\
\text { Coklat }\end{array}$ & $\begin{array}{c}\text { Delfinidin } \\
\text { - }\end{array}$ \\
\hline
\end{tabular}

Keterangan: Berdasarkan referensi untuk ciri antosianidin umum pada Tabel 1 (Harborne, 1987) 
Spot berwarna ungu pada fase gerak forestal memiliki nilai Rf 34,92; format memiliki nilai Rf 14,03 dan BAA (n-butanol:asam asetat:akuades) memiliki nilai $\operatorname{Rf} 42,31$. Bila dicocokkan dengan tabel referensi (Tabel 1) spot berwarna ungu dan nilai Rf KLT buah tomi-tomi dari ketiga fase gerak menunjukkan1 jenis antosianidin yaitu delfinidin. Setelah penentuan jenis antosianidin dengan KLT, maka langkah selanjutnya yaitu dilakukan pemindaian panjang gelombang maksimum dalam Metanol-HCl untuk mengonfirmasi hasil yang telah di dapat pada KLT. Pada pemindaian ini juga akan dilakukan reaksi geser dengan menggunakan $\mathrm{AlCl}_{3}$ untuk melihat adanya pergeseran panjang gelombang maksimum.

Fase gerak yang menghasilkan pemisahan yang baik pada hasil KLT disajikan pada Gambar 1, yaitu forestal, sehingga dilakukan KLT preparatif untuk pemindaian panjang gelombang maksimum jenis antosianidinnya. Antosianidin yang digunakan untuk KLT preparatif yaitu ekstrak buah tomi-tomi kasar yang telah di hidrolisis asam, sedangkan untuk pemindaian panjang gelombang maksimum jenis antosianidin ini menggunakan spot dari KLT preparatif. Hasil pemindaian panjang gelombang maksimum buah tomi-tomi dapat dilihat pada Tabel 3 .

Hasil pemindaian panjang gelombang maksimum dengan fase gerak forestal terlihat pada panjang gelombang $537 \mathrm{~nm}$. Menurut Lestario et al. (2011) ada pemindaian absorbansi maksimum yang ditambahkan dengan dengan $\mathrm{AlCl}_{3}$ untuk melihat ada atau tidaknya pergeseran batokromik, yang menandakan ada atau tidaknya gugus ortohidroksi. Antosianidin yang memiliki gugus ortohidroksi yaitu, delfinidin, sianidin, dan petunidin yang akan bereaksi positif dengan $\mathrm{AlCl}_{3}$. Adanya reaksi positif dengan $\mathrm{AlCl}_{3}$ ditandai dengan terbentuknya kelat berwarna biru yang menimbulkan pergeseran absorbansi maksimum ke arah panjang gelombang yang lebih besar. Pemindaian panjang gelombang maksimum ini menggunakan spot dari KLT preparatif. Hasil penelitian menunjukkan terjadinya pergeseran batokromik sebesar $3 \mathrm{~nm}$ (537-540 nm) (Nusantara et al., 2017). Antosianin yang mengikat satu gula (monosakarida) akan menghasilkan efek batokromik yang lebih besar dibandingkan dengan antosianin yang mengikat tiga gula (trisakarida) maupun antosianin yang terasilasi dengan asam organik (Nusantara et al., 2017). Bila dicocokkan dengan tabel referensi (Tabel 1) panjang gelombang ini cocok dengan antosianidin jenis sianidin. Hal ini dikarenakan sianidin dengan warna merah ungu ini memiliki panjang gelombang maksimum $535 \mathrm{~nm}$ dan memiliki geser batokromik dengan adanya $\mathrm{AlCl}_{3}$ (Harborne, 1987), sehingga pendugaan sementara antosianidin buah tomi-tomi adalah sianidin. Hasil ini tidak sesuai dengan KLT antosianidin yang menunjukkan delfinidin. Hal ini mungkin disebabkan karena ekstrak yang digunakan untuk pemindaian panjang gelombang maksimum terlalu encer atau antosianidin tersebut sudah mengalami degradasi selama proses hidrolisis. Untuk memastikan hal tersebut, maka analisis KCKT dilakukan untuk mendeteksi jenis antosianidin dalam buah tomi-tomi.

Analisis KCKT ekstrak buah tomi-tomi kasar yang telah di hidrolisis asam menghasilkan 10 puncak (Gambar 2). Analisis dilakukan dengan membandingkan waktu retensi antosianidin buah tomitomi dengan waktu retensi standar antosianidin.

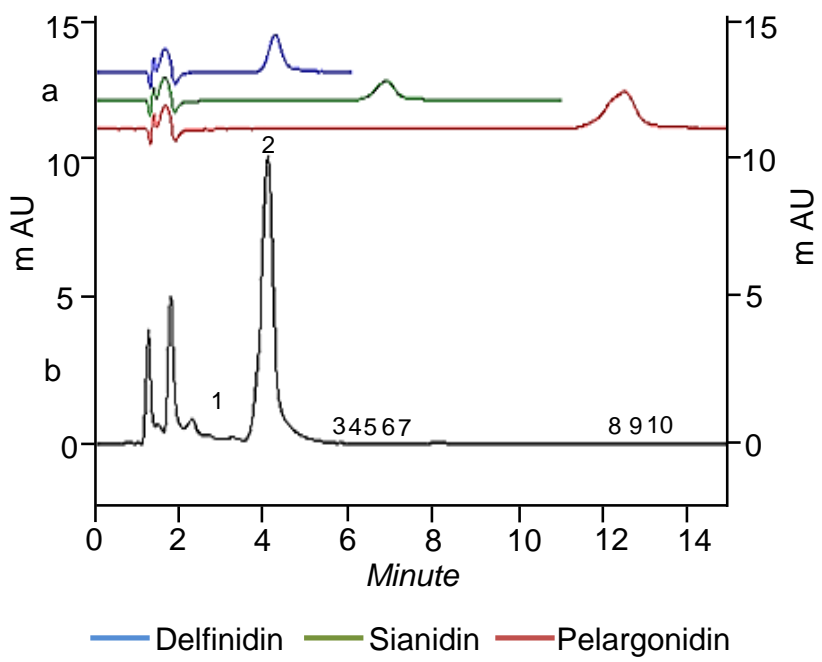

Keterangan: (a) -delfinidin ( $\mathrm{t}_{\mathrm{R}}=4,267$ menit), -sianidin ( $\mathrm{t}_{\mathrm{R}}=$ 6,900 menit), -pelargonidin ( $t_{R}=12,517$ menit) dan (b) puncak 2 : delfinidin ( $t_{R}=4,083$ menit)

Gambar 2. Kromatogram KCKT. (a) antosianidin murni, (b) antosianidin buah tomi-tomi. Fase diam:Eurosphere 100-5 C18, $150 \times 4,6 \mathrm{~mm}$. Fase gerak:10\% asam formik:asetonitril $(85: 15)$ isokratik. Kecepatan alir:1,2 $\mathrm{mL} / \mathrm{min}$. Volume injeksi :20 mL. Detektor: UV detector 2500, $530 \mathrm{~nm}$

Pada Gambar 2 terlihat ada 1 puncak yang dominan dengan waktu retensi 4,083 menit yang sesuai dengan waktu retensi standar antosianidin jenis delfinidin (4,267 menit).

Tabel 3. Data pemindaian panjang gelombang maksimum ekstrak antosianidin buah tomi-tomi

\begin{tabular}{|c|c|c|c|c|c|}
\hline \multirow{2}{*}{ Fase gerak } & \multicolumn{2}{|c|}{$\lambda$ maks $(\mathrm{nm})$} & \multirow{2}{*}{$\begin{array}{l}\lambda \text { maks sesudah di } \\
+\mathrm{AlCl}_{3}(\mathrm{~nm})\end{array}$} & \multirow{2}{*}{$\begin{array}{l}\text { Pergeseran } \\
\text { Batokromik** }\end{array}$} & \multirow{2}{*}{ Pendugaan* } \\
\hline & Teori $^{\star}$ & Penelitian & & & \\
\hline Fores & 535 & 537 & 540 & $(+)$ & Sianidin \\
\hline
\end{tabular}

Keterangan: *Berdasarkan referensi untuk ciri antosianidin umum pada Tabel 1 (Harborne, 1987); ${ }^{* *}(+)$ ada pergeseran batokromik 
Hasil ini sesuai dengan nilai $\mathrm{Rf}$ antosianidin (Tabel 2) yang diduga jenis delfinidin, namun, tidak sesuai dengan pemindaian panjang gelombang maksimum yang menunjukkan sianidin. Pada KCKT ini sianidin berada pada persen area yang sangat rendah sehingga dapat dikatakan tidak terdeteksi. $\mathrm{Hal}$ ini mungkin disebabkan oleh ekstrak yang digunakan untuk KCKT terlalu encer (konsentrasinya kecil) dan atau antosianidin tersebut telah mengalami degradasi selama proses hidrolisis.

Hasil analisis dengan KCKT ini menunjukkan bahwa buah tomi-tomi mengandung antosianidin jenis delfinidin dengan kadar $0,0263 \mathrm{mg} / \mathrm{g}$. Jenis antosianidin buah tomi-tomi memiliki komposisi antosianidin yang hampir sama dengan anggur (concord grape), buah duwet, dan jantung pisang klutuk, namun berbeda dalam kadar atau presentase relatifnya. Antosianidin utama pada anggur concord adalah delfinidin dan sianidin, pada buah duwet adalah delfinidin, petunidin, dan malvidin (Sari et al., 2009) dan pada jantung pisang klutuk adalah delfinidin dan sianidin.

\section{Jenis gula}

Pada penentuan jenis antosianin hal yang pertama dilakukan yaitu menentukan jenis gula. Hasil penelitian menunjukkan bahwa fase gerak BAA (nbutanol:asam asetat:akuades) dan BEA (n-butanol: etanol:akuades) menghasilkan 1 spot yang berwarna coklat. Spot yang berada di sebelah kiri merupakan standar glukosa dan spot yang berada di sebelah kanan merupakan spot dari buah tomi-tomi. Hasil tersebut dapat dilihat pada Gambar 3 dan Tabel 4.

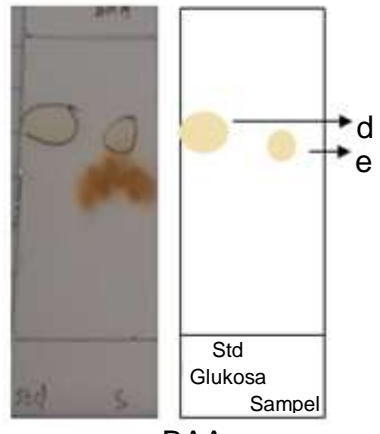

BAA

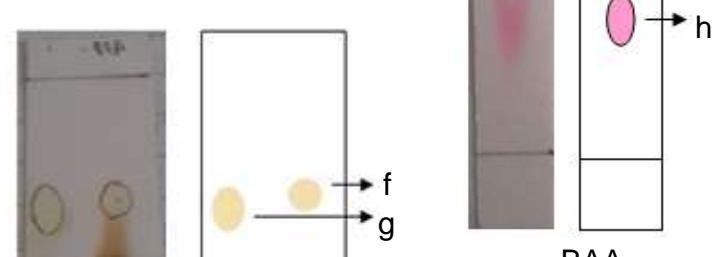

BAA
Gula merupakan senyawa tanpa warna bila terdapat dalam jumlah yang kecil, sehingga harus dideteksi dengan pereaksi kromogen yang cocok. Pada penelitian ini digunakan pereaksi anilin hidrogen ftalat untuk memastikan bahwa gula dioksidasi secara khas menjadi senyawa yang tidak bereaksi lagi (Harbrone, 1987). Pada penelitian ini spot yang dihasilkan buah tomi-tomi setelah direaksikan dengan anilin hidrogen ftalat berwarna coklat dengan fase gerak BAA (n-butanol:asam asetat:akuades) dan BEA (n-butanol:etanol:akuades) menghasilkan nilai Rf 65,91 dan 53,33 . Nilai Rf ini hampir sama dengan nilai $\mathrm{Rf}$ standar glukosa dengan fase gerak yang sama dan kondisi yang sama yaitu 68,18 pada Butanol-asam asetat-akuades dan 51,11 pada Butanol-etanol-akuades sehingga dari hasil ini gula yang terikat pada antosianin buah tomi-tomi adalah glukosa.

\section{Jenis antosianin}

Antosianin buah tomi-tomi ditentukan dengan KLT selulosa dengan 3 fase gerak yaitu BAA ( $n$ butanol:asam asetat:akuades), Butanol- $\mathrm{HCl}$, dan $\mathrm{HCl} 1 \%$. Pada penentuan jenis antosianin ini digunakan ekstrak buah tomi-tomi yang telah di maserasi dengan Metanol-HCl 1\%. Hasil pemisahan antosianin dengan KLT dapat dilihat pada Gambar 4 dan Tabel 5.
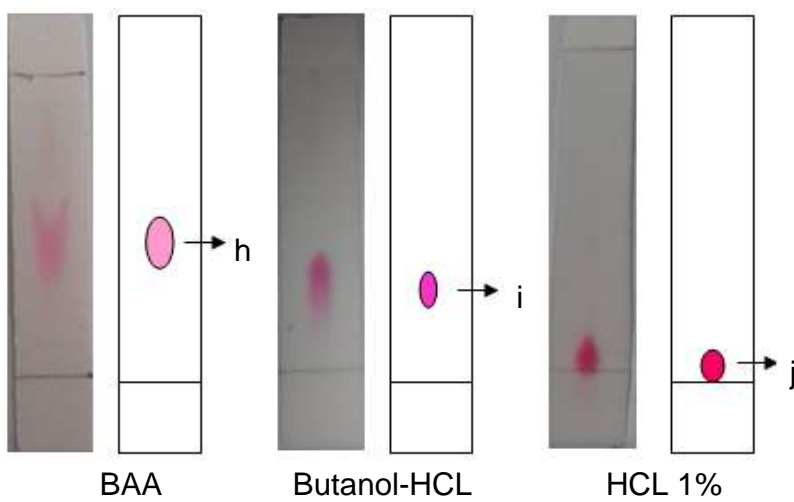

Keterangan: Jarak atas pergerakan pelarut BAA, BuHCl dan $\mathrm{HCl} 1 \%$ berturut-turut adalah 4,0; 3,4 dan $4,6 \mathrm{~cm}$. Jarak batas bawah dan atas pelarut pelarut BAA, $\mathrm{BuHCl}$ dan $\mathrm{HCl} 1 \%$ berturut-turut adalah 5,0; 5,0 dan $5,0 \mathrm{~cm}$. Jarak pergerakan spot pelarut pelarut BAA, $\mathrm{BuHCl}$ dan $\mathrm{HCl} 1 \%$ berturut-turut adalah 1,5;0,9 dan $0,2 \mathrm{~cm}$

terangan: Jarak atas pergerakan pelarut BAA dan $B E A$ adalah 4,4 dan $4,5 \mathrm{~cm}$. Jarak batas bawah dan atas pelarut BAA dan BEA adalah $5,0 \mathrm{~cm}$. Jarak pergerakan spot standar pelarut BAA dan BEA adalah 3,0 dan 2,3 $\mathrm{cm}$ jarak pergerakan spot sampel pelarut BAA dan BEA adalah 2,9 dan $2,4 \mathrm{~cm}$

Gambar 3. Kromatogram gula buah tomi-tomi dengan KLT. Fase diam:plat silika gel. Fase gerak:BAA (n-butanol:asam asetat:akuades $=4: 1: 5, \mathrm{v} / \mathrm{v} / \mathrm{v})$ dan BEA $(\mathrm{n}$ butanol:etanol:akuades $=4: 1: 2,2, \mathrm{v} / \mathrm{v} / \mathrm{v})$
Gambar 4. Kromatogram antosianin buah tomitomi dengan KLT. Fase diam:plat selulosa. Fase gerak:BAA (n-butanol:asam asetat:akuades $=4: 1: 5, \mathrm{v} / \mathrm{v} / \mathrm{v})$, Butanol$\mathrm{HCl}(\mathrm{n}$-butanol: $\mathrm{HCl} 2 \mathrm{M}=1: 1, \mathrm{v} / \mathrm{v})$ dan $\mathrm{HCl} 1 \%$ (akuades: $\mathrm{HCl}$ pekat $=97: 3, \mathrm{v} / \mathrm{v}$ )

Fase gerak yang menghasilkan profil kromatogram yang baik (spot yang tidak tailing) yaitu Butanol-HCl, sehingga dilakukan KLT preparatif un- 
tuk menentukan pola substitusi glikosidasi antosianin buah tomi-tomi. Hasil KLT dan pemindaian absorbansi maksimum ekstrak antosianin dapat dilihat pada Gambar 5 dan Tabel 6. Data spektrum memberikan informasi tentang keberadaan gugus asil pada molekul antosianin. Keberadaan gugus asil sendiri dapat dideteksi dengan adanya puncak pada spektrum daerah panjang gelombang 310-340 nm (Sari et al., 2009). Pada spektrum antosianin buah tomi-tomi tidak ditemukan absorbansi maksimum pada daerah $310-340 \mathrm{~nm}$ yang menandakan tidak ada asilasi asam organik aromatik (asam sinamat) pada antosianin buah tomi-tomi.
Selain itu juga, pola substitusi glikosidasi antosianin umumnya digunakan nisbah $A_{440 \mathrm{~nm}} / \mathrm{A}_{\lambda \mathrm{maks}}$ untuk menunjukkan perbedaan pola glikosidasi antosianin di posisi 3-glikosida atau 3,5-diglikosida (Lestario et al., 2011). Pada Tabel 6 menunjukkan bahwa panjang gelombang maksimum di $533 \mathrm{~nm}$ dan nisbah $A_{440 \mathrm{~nm}} / A_{\lambda \text { maks }}$ sebesar $42,47 \%$. Nisbah ini menunjukkan bahwa seluruh antosianin buah tomitomi mengandung glikosida pada posisi 3 (3-glikosida). Dari semua informasi tersebut, maka antosianin buah tomi-tomi diduga delfinidin 3-glukosida dan sianidin 3-glukosida.

Tabel 4. Nilai Rf KLT gula buah tomi-tomi dan standar glukosa dengan fase gerak BAA (n-butanol:asam asetat:akuades), Butanol- $\mathrm{HCl}$, dan $\mathrm{HCl} 1 \%$

\begin{tabular}{lccccc}
\hline \multirow{2}{*}{ Fase Gerak } & \multicolumn{2}{c}{ Rf $(\times 100)$} & \multicolumn{2}{c}{ Warna dengan Anilin Hidrogen Ftalat ${ }^{\star *}$} & \multirow{2}{*}{ Pendugaan* $^{*}$} \\
\cline { 2 - 5 } & Standar Glukosa & Spot Buah Tomi-Tomi & Warna Tampak & Warna UV 254 nm & \\
\hline BAA & $\mathrm{d}=68,18$ & $\mathrm{e}=65,91$ & Coklat & Coklat & Glukosa \\
BEA & $\mathrm{f}=51,11$ & $\mathrm{~g}=53,33$ & Coklat & Coklat & Glukosa \\
\hline
\end{tabular}

Keterangan: *Sama dengan standard glukosa; ${ }^{*}$ Dibuat dengan melarutkan anilina $(9,2 \mathrm{~mL})$ dan asam ftalat (16 g) dalam butanol $(490 \mathrm{~mL})$, etanol $(490 \mathrm{~mL})$ dan akuades $(20 \mathrm{~mL})$ (Harbrone, 1987)

Tabel 5. Nilai Rf KLT antosianin buah tomi-tomi dengan fase gerak BAA (n-butanol:asam asetat:akuades) dan BEA (n-butanol:etanol:akuades)

\begin{tabular}{lccccc}
\hline Fase Gerak & $\begin{array}{c}\text { Rf Sampel } \\
\times 100\end{array}$ & Warna Tampak & $\begin{array}{c}\text { Warna UV 254 } \\
\mathrm{nm}\end{array}$ & $\begin{array}{c}\text { Rf teori } \\
\times 100^{*}\end{array}$ & Pendugaan* $^{*}$ \\
\hline BAA & $\mathrm{h}=37,50$ & Ungu & Ungu & 38 & Sianidin 3-glukosida \\
Butanol-HCl & $\mathrm{i}=26,47$ & Ungu & Ungu & 25 & Sianidin 3-glukosida \\
$\mathrm{HCl} 1 \%$ & $\mathrm{j}=04,30$ & Merah muda & Merah muda & 3 & Delfinidin 3-glukosida \\
\hline
\end{tabular}

Keterangan: *(Harbrone, 1987)

Tabel 6. Data pemindaian absorbansi maksimum ekstrak antosianin buah tomi-tomi

\begin{tabular}{cccccc}
\hline Fase Gerak & Warna Tampak & Warna UV $254 \mathrm{~nm}$ & $\lambda$ maks $^{\mathrm{a}}(\mathrm{nm})$ & $\left.\mathrm{A}_{440 \mathrm{~nm}} / \mathrm{A}_{\lambda \text { maks }}{ }^{\mathrm{b}} \%\right)$ & Pendugaan $^{\mathrm{c}}$ \\
\hline Butanol-HCl & Ungu & Ungu & $533(0,186)$ & 42,47 & $\begin{array}{c}\text { Antosianidin 3- } \\
\text { glukosida }\end{array}$ \\
\hline
\end{tabular}

Keterangan: a Panjang gelombang daerah visibel yang menghasilkan nilai absorbansi maksimum; ${ }^{b}$ Nisbah nilai absorbansi pada panjang gelombang $440 \mathrm{~nm}$ dengan nilai absorbansi maksimum pada panjang gelombang daerah visibel; ${ }^{\mathrm{c}}$ (Harborne, 1987)

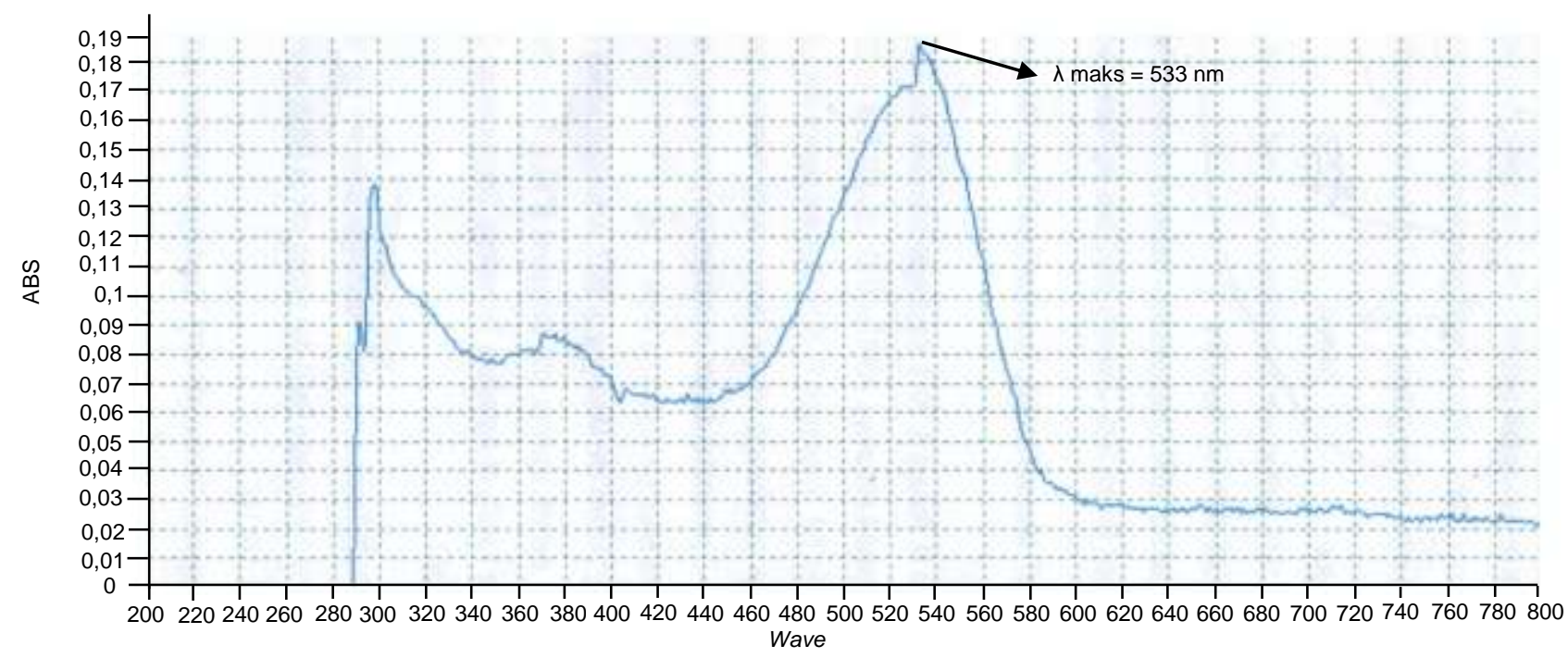

Gambar 5. Hasil pemindaian absorbansi maksimum ekstrak antosianin buah tomi-tomi dengan fase gerak Butanol- $\mathrm{HCl}$ 


\section{KESIMPULAN}

Berdasarkan hasil penelitian, dapat disimpulkan bahwa kandungan antosianin total buah tomitomi yang ditentukan dengan metode perbedaan $\mathrm{pH}$ sebesar $26,56 \pm 0,28 \mathrm{mg} / 100 \mathrm{~g}$ berat basah atau $103,89 \pm 1,08 \mathrm{mg} / 100 \mathrm{~g}$ berat kering. Berdasarkan nilai Rf pada KLT dan waktu retensi puncak HPLC, dipastikan bahwa antosianidin jenis delfinidin. $\mathrm{Na}$ mun, data absorbansi panjang gelombang maksimum pada spot KLT menunjukkan sianidin. Mungkin, ini dikarenakan ekstrak yang digunakan terlalu encer atau antosianidin telah terdegradasi selama proses hidrolisis. Berdasarkan nilai Rf pada KLT dan pola glikosidasi pada Spektrofotometer UV-Vis, diduga antosianin jenis Sianidin 3-glukosida dan delfinidin 3-glukosida.

\section{UCAPAN TERIMA KASIH}

Penulis mengucapkan terimakasih kepada Kemenristek Dikti yang telah mendanai penelitian ini melalui dana PTUPT (Penelitian Terapan Unggulan Perguruan Tinggi) tahun anggaran 2018 Nomor SP DIPA-042.06.1.401516/2018.

\section{DAFTAR PUSTAKA}

Ali F, Ferawati, Arqomah R. 2013. Ekstraksi zat warna dari kelopak bunga rosella (study pengaruh konsentrasi asam asetat dan asam sitrat). J Teknik Kimia 19: 26-34.

Alvionita J, Darwis D, Efdi M. 2016. Ekstraksi dan identifikasi senyawa antosianin dari jantung pisang raja (Musa $X$ paradisica L.) serta uji aktivitas antioksidannya. J Riset Kimia 9: 21-28. DOI: 10.25077/jrk.v9i2.284.

Anggriani R, Ain N, Adnan S. 2017. Identifikasi fitokimia dan karakterisasi antosianin dari sabut kelapa hijau (Cocos mucifera L. var varidis). J Teknol Pertanian 18: 163-172.

Harborne JB. 1987. Metode Fitokimia, Penentuan Cara Modern Menganalisis Tumbuhan. 78-84. Penerbit ITB, Bandung.

Harborne JB. 1996. Metode Fitokimia, Penentuan Cara Modern Menganalisis Tumbuhan. 86. Penerbit ITB, Bandung.

Husna NE, Novita M, Rohaya S. 2013. Kandungan antosianin dan aktivitas antioksidan ubi jalar ungu segar dan produk olahannya. Agritech 33: 296-302.
Latumaerissa ET, Lestario LN, Muninggar J. 2017. Antioxidant activity of anthocyanin of tomi-tomi fruit (Flacourtia inermis) against total cholesterol in mice. Proceeding of $4^{\text {th }}$ International Student Conference Faculty of Agriculture Technology, Soegijapranata Catholic University.

Lestario LN, Rahayuni E, Timotius KH. 2011. Kandungan antosianin dan identifikasi antosianidin dari kulit buah jenitri (Eleaocarpus angustifolius). Agritech 31: 93-101. DOI: 10.22146/agri tech.9731.

Lestari PP, Kusrini D, Anam K. 2014. Anthocyanin identification of methanol- $\mathrm{HCl}$ extract active fraction in rosella (Hibiscus sabdariffa. L) and its potential as xanthine oxidase inhibitor. J Sains Matematika 22: 72-78.

Markakis P. 1982. Anthocyanins as Food Additives. Dalam P. Markakis, (ed) Anthocyanins as Food Color. 169-170. Academic Press, New York.

Nusantara YP, Lestario, LN, Martono Y. 2017. Pengaruh penambahan asam galat sebagai kopigmen antosianin murbei hitam (Morus nigra L.) terhadap stabilitas termal. Agritech 37: 428436. DOI: 10.22146/agritech.22963.

Reis JF, Monteiro VVS, Gomes RDS, Carmo MM, Costa GV, Ribera PC, Monteiro MC. 2016. Action mechanism and cardiovascular effect of anthocyanins: a systematic review of animal and human studies. J Transl Med 14: 315. DOI: 10. 1186/s12967-016-1076-5.

Sari P, Wijaya CH, Sajuthi D, Supratman U. 2009. Identifikasi antosianin buah duwet (Syzygium cumini) menggunakan kromatografi cair kinerja tinggi-Diode array detection. J Teknol Industri Pangan 20: 102-108.

Sotyati. 2016. Lobi-lobi, simpan khasiat perangi kolestrol. http://www.satuharapan.com/read-detail/ read/lobi-lobi-simpan-khasiat-perangi-kolestrol [17 Juni 2017].

Stefanut MN, Cata A, Pop R, Mosoarca C, Zamfir AD. 2011. Anthicyanins HPLC-DAD and MS characterization, total phenolics, and antioxidant activity of some berries extracts. Anal Let 44: 2843-2855. DOI: 10.1080/00032719.2011.5 82550.

Sutharut J, Sudarat J. 2012. Total anthocyanin content and antioxidant activity of germinate colored rice. Int Food Res J 19: 215-221.

Weber F, Larsen LR. 2017. Influence of fruit juice processing on anthocyanin stability. Food Res Int 100: 354-365. DOI: 10.1016/j.foodres.2017. 06.033 . 